\title{
Analisis Kinerja Keuangan Perusahaan pada PT. Japfa Comfeed Indonesia Tbk
}

\author{
Jezzyca Ria Paramita ${ }^{1^{*}}$, Iwan Eka Putra ${ }^{2 *}$, Abd Halim $^{3}$, Ermaini $^{4}$ \\ ${ }^{1,2,3}$ Universitas Muhammadiyah Jambi \\ *Correspondence email: rjezzyca@gmail.com
}

\begin{abstract}
Financial performance is an overview of how a company's financial condition is. To assess financial performance is used with a benchmark commonly called financial ratios. Financial ratios used are usually such as profitability ratio, liquidity ratio and solvency ratio. in addition to using financial ratios, the company can also use the Altman Z-Score method to assess the level of the company's bankruptcy prediction. This research aims to find out the financial performance of PT Japfa Comfeed Indonesia Tbk as well as the company's future bankruptcy predictions. the research method used is quantitative analysis based on secondary data taken from the Financial Statements of PT Japfa Comfeed Indonesia Tbk for the period 2014 to 2019. The results of the study are measurements of the company's financial ratio showing sufficient value while measurements using the company's Altman Z-Score method show healthy value which means it does not go into bankruptcy.
\end{abstract}

\section{Keywords: Financial Ratio, Bankruptcy Prediction, Financial Performance}

\section{Pendahuluan}

Keberhasilan suatu perusahaan biasanya diukur dengan Kinerja Keuangan perusahaan tersebut. Kinerja keuangan perusahaan yang baik dan bagus akan menjadi nilai plus bagi para investor untuk menanamkan modalnya di perusahaan tersebut. Baik dan Buruknya kinerja keuangan perusahaan dapat dinilai melalui laporan keuangan perusahaan yang disajikan secara teratur. Bagi pihak-pihak yang memiliki kepentingan terhadap perkembangan suatu perusahaan sangat perlu untuk mengetahui kondisi kinerja keuangan perusahaan yang tercermin dalam laporan keuangan. Kinerja keuangan perusahaan dapat dinilai melalui laporan keuangan yang disajikan pada setiap periode. Laporan keuangan merupakan hasil dari proses akuntansi yang digunakan sebagai alat untuk berkomunikasi dengan pihak-pihak yang berkepentingan dengan data keuangan perusahaan. (Haq, 2013).

Pihak yang berkepentingan salah satunya adalah manajer. Setiap periode manajer akan melihat laporan keuangan sehingga dapat mengukur bagaimana kinerja perusahaanya dalam periode tersebut. Fungsinya adalah agar manajer dapat menganalisis serta dapat mengambil keputusan untuk periode selanjutnya agar kinerja keuangan perusahaanya akan semakin baik tiap-tiap periodenya. Analisis keuangan perusahaan dilakukan dengan menggunakan indikator laporan keuangan perusahaan yang bersangkutan. Berdasarkan laporan keuangan akan dapat dihitung sejumlah rasio keuangan yang wajar dijadikan sebagai dasar penilaian terhadap kinerja suatu perusahaan. Setiap Rasio keuangan memiliki artian yang berbeda-beda. (Agustin, 2016)

Selain dari rasio, kinerja perusahaan juga bisa diukur dengan seberapa baik perusahaan tersebut menjauh dari kondisi kebangkrutan. Dengan perusahaan yang jauh dari kata bangkrut maka berarti perusahaan memiliki kondisi kinerja yang baik. Tujuan dari Penelitian ini yaitu untuk mengetahui kinerja keuangan perusahaan, untuk mengetahui kondisi standar Bangkrut atau tidaknya perusahaan dalam beberapa tahun kedepan serta untuk menganalisa kinerja keuangan perusahaan.

\section{Analisis Laporan Keuangan}

Menurut Koesnina (2011), laporan keuangan adalah catatan informasi keuangan suatu perusahaan pada suatu periode akuntansi yang dapat digunakan untuk menggambarkan kinerja perusahaan tersebut. Laporan keuangan merupakan bagian dari proses pelaporan keuangan. Laporan keuangan terdiri atas dua laporan utama dan beberapa laporan yang sifatnya sebagai pelengkap. Menurut Munawir (2010), analisis laporan keuangan yang terdiri dari penelaahan atau mempelajari daripada hubungan dan tendensi atau kecenderungan (Trend) untuk menentukan posisi keuangan dan hasil operasi serta perkembangan perusahan yang bersangkutan. Dengan kata lain, analisis laporan keuangan adalah cara yang digunakan seseorang dalam memahami serta mengetahui bagaimana kondisi keuangan perusahaan yang mereka miliki saat ini.

\section{Kinerja Keuangan}

kinerja keuangan adalah suatu kegiatan yang dilakukan perusahaan dalam mengukur prestasi perusahaan dan menggunakan modal secara efektif dan efisien demi tercapainya tujuan perusahaan. Apabila kinerja keuangan perusahaan baik maka nilai usaha akan tinggi, dengan nilai usaha yang tinggi membuat para investor melirik perusahaan tersebut untuk menanamkan modalnya sehingga akan terjadi kenaikan harga saham. Sebaliknya apabila 
terdapat berita buruk mengenai kinerja keuangan perusahaan maka akan menyebabkan penurunan harga saham pada perusahaan tersebut.

\section{Analisis Prediksi Kebangkrutan}

Kondisi ekonomi global sering tidak terprediksi. Saat ekonomi suatu negara mengalami kemajuan, negara lain mengalami kemunduran. Keadaan ekonomi yang tidak menguntungkan membuat beberapa perusahaan bangkrut. Untuk mengukur tingkat kebangkrutan ada beberapa cara yang digunakan misalnya dengan menggunakan analisis prediksi kebangkrutan dengan menggunakan metode Altman Z-Score. Dimana Metode Z-Score (Altman) adalah skor yang ditentukan dari hitungan standar kali nisbah-nisbah keuangan yang akan menunjukan tingkat kemungkinan kebangkrutan perusahaan (Supardi, 2003).

\section{Hasil}

Net Profit Margin adalah rasio yang menunjukan keuntungan penjualan setelah menghitung biaya dan pajak penghasilan. Semakin tinggi rasio ini semakin baik karena kemampuan perusahaan mendapatkan laba cukup tinggi.

Tabel 1

Net Profit Margin (NPM) PT Japfa Comfeed Indonesia Tbk

\begin{tabular}{|c|c|c|}
\hline Tahun & NPM & Perkembangan \\
\hline 2014 & $1,57 \%$ & 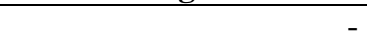 \\
\hline 2015 & $2,09 \%$ & $33,12 \%$ \\
\hline 2016 & $8,02 \%$ & $283,73 \%$ \\
\hline 2017 & $3,74 \%$ & $(53,37 \%)$ \\
\hline 2018 & $6,62 \%$ & $77,01 \%$ \\
\hline 2019 & $5,12 \%$ & $(22,66 \%)$ \\
\hline Rata-rata Perusahaan & & $4,53 \%$ \\
\hline Standar Industri & & $20 \%$ \\
\hline
\end{tabular}

Sumber: Laporan Keuangan PT Japfa Comfeed Indonesia Tbk (data diolah)

Kinerja Keuangan PT Japfa Comfeed Indonesia Tbk dari periode 2014 sampai dengan tahun 2019 dihitung melalui Net Profit Margin serta standar industri berada dalam kondisi sangat kurang. Karena nilai yang ditunjukan pada 6 tahun tersebut masi dibawah 20\%. Hal ini dikarenakan karena pertumbuhan ekonomi indonesia tidak sesuai dengan yang diharapkan. Melambatkanya pertumbuhan ekonomi global serta menguatnya nilai tukar dolar amerika serikat terhadap rupiah sangat mempengaruhi pertumbugan ekonomi indonesia dan mengakibatkan menurunnya daya beli masyarakat. Return On Assets merupakan pengukuran kemampuan perusahaan secara keseluruhan di dalam menghasilkan keuntungan dengan jumlah aktiva yang tersedia di dalam perusahaan. Semakin tinggi rasio, semakin baik keadaaan perusahaan.

Tabel 2

Return on Asset (ROA) PT Japfa Comfeed Indonesia Tbk

\begin{tabular}{|c|c|c|}
\hline Tahun & ROA & Perkembangan \\
\hline 2014 & $2,44 \%$ & 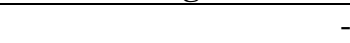 \\
\hline 2015 & $3,05 \%$ & $25,0 \%$ \\
\hline 2016 & $11,28 \%$ & $269,83 \%$ \\
\hline 2017 & $5,25 \%$ & $(53,45 \%)$ \\
\hline 2018 & $9,78 \%$ & $86,28 \%$ \\
\hline 2019 & $7,48 \%$ & $(23,51 \%)$ \\
\hline Rata-rata Perusahaan & & $6,55 \%$ \\
\hline Standar Industri & & $30 \%$ \\
\hline
\end{tabular}

Sumber : Laporan Keuangan PT Japfa Comfeed Indonesia Tbk (data diolah)

Kinerja keuangan PT Japfa Comfeed Indonesia Tbk periode 2014 sampai dengan 2019 ditinjau dari Return On Assets mengalami naik turun. Hal ini dikarenakan nilai penjualan mengalami naik turun di setiap tahunnya. Kondisi perusahaan juga masi dikatakan sangat kurang karena nilai Return On Assets perusahaan 6 tahun belakangan masih di bawah standar industri yakni 30\%. Rasio ini menunjukan berapa persen diperoleh laba bersih diukur dari modal pemilik. Rasio ini juga dipengaruhi oleh besar kecilnya utang perusahaan. 
Tabel 3

Return on Asset (ROE) PT Japfa Comfeed Indonesia Tbk

\begin{tabular}{|c|c|c|}
\hline Tahun & ROE & Perkembangan \\
\hline 2014 & $7,27 \%$ & 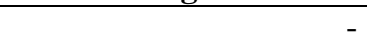 \\
\hline 2015 & $8,58 \%$ & $18,01 \%$ \\
\hline 2016 & $23,16 \%$ & $169,93 \%$ \\
\hline 2017 & $11,30 \%$ & $(51,20 \%)$ \\
\hline 2018 & $22,05 \%$ & $95,13 \%$ \\
\hline 2019 & $16,45 \%$ & $(25,39 \%)$ \\
\hline Rata-rata Perusahaan & & $14,8 \%$ \\
\hline Standar Industri & & $40 \%$ \\
\hline
\end{tabular}

Sumber : Laporan Keuangan PT Japfa Comfeed Indonesia Tbk (data diolah)

Nilai ROE perusahaan untuk tahun 2014 bernilai 7,27\% yang berarti setiap modal yang ditanamkan sebesar Rp 100,- pemilik atau investor akan mendapatkan keuntunga sebesar 7,27\%. Pada tahun 2015 dan 2016 nilai ROE Perusahaan mengalami kenaikan masing-masing sebesar 18,01\% dan yang tertinggi 169,93\%.. Namun walau sudah mengalami peningkatan terutama di tahun 2016 kondisi perusahaan masih sangat kurang jika di lihat dari standar industri yakni di bawah 40\%. Pada tahun 2017 nilai ROE mengalami penurunan sebesar 51,20\% menjadi 11.3. Tahun 2018 nilai ROE Perusahaan kembali mengalami kenaikan walau tidak setinggi tahun 2016 tetapi dapat cukup bisa dikatakan tinggi juga yakni bertambah 95,13\% dari tahun sebelumnya menjadi 22,05\%. Dan terakhir tahun 2019 nilai ROE perusahaan lagi-lagi mengalami penurunan sebesar 25,39\% menjadi $16,45 \%$.Kinerja keuangan PT Japfa Comfeed Indonesia Tbk pada periode 2014 sampai dengan 2019 dapat dilihat mengalami naik turun. Tetapi masi pada kondisi sangat kurang di karenakan nilai ROE perusahaan masi dibawah standar industri yakni dibawah $40 \%$.

Current ratio (rasio lancar) adalag rasio yang digunakan untuk membandingkan antara aset yang dimiliki perusahaan dengan kewajiban jangka pendek. Dengan kata lain seberapa banyak aset lancar yang tersedia untuk menutupi kewajiban perusahaan yang segera jatuh tempo.

Tabel 4

Current Ratio (CR) PT Japfa Comfeed Indonesia Tbk

\begin{tabular}{|c|c|c|}
\hline Tahun & Current Ratio & Perkembangan \\
\hline 2014 & $177,14 \%$ & 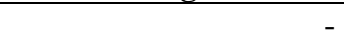 \\
\hline 2015 & $179,42 \%$ & $1,28 \%$ \\
\hline 2016 & $212,97 \%$ & $18,69 \%$ \\
\hline 2017 & $234,59 \%$ & $10,15 \%$ \\
\hline 2018 & $179,82 \%$ & $(23.34 \%)$ \\
\hline 2019 & $173,33 \%$ & $(3.60 \%)$ \\
\hline Rata-rata Perusahaan & & $192,88 \%$ \\
\hline Standar Industri & & $200 \%$ \\
\hline
\end{tabular}

Sumber : Laporan Keuangan PT Japfa Comfeed Indonesia Tbk (data diolah)

Berdasarkan Tabel 4 di atas menunjukan nilai rasio lancar perusahaan ialah 177,14\% yang berarti setiap hutang lancar perusahaan sebesar Rp 100,- akan di jamin dengan Rp 177,14,-. Nilai rasio pada tahun 2014 ini jika dibandingkan dengan standar industri untuk rasio lancar maka perusahaan dapat dikatakan dalam kondisi baik. Pada tahun 2015 rasio lancar perusahaan mengalami perkembangan sebesar 1,28\% sehingga nilai rasio lancar perusahaan pada tahun 2015 menjadi 179,42\%. Pada tahun 2016 rasio perusahaan mengalami perkembangan yang paling pesat yakni terjadi peningkatan sebesar 18,69\% dari tahun sebelumnya. Pada tahun 2017 perusahaan kembali mengalami kenaikan untuk nilai rasio lancar sebesar 10,15\% menjadi 234,59\%. Pada tahun 2018 dan 2019 perusahaan mengalami penurunan masing-masing sebesar 23,34\% dan 3,6\%. Kinerja keuangan PT Japfa Comfeed Indonesia Tbk periode 2014 sampai dengan 2019 memiliki nilai rata-rata sebesar 192,88\% yang berarti dalam kondisi cukup baik. Kinerja perusahaan memiliki kinerja paling baik berada pada tahun 2016 dan 2017 karena berada di atas nilai standar industri.

Rasio yang mengukur kemampuan suatu perusahaan untuk membayar kewajiban jangka pendek tanpa mengandalkan penjualan persediaan sangat penting artinya, dengan kata lain seberapa banyak aset lancar dikurangi persediaan yang tersedia untuk memenuhi kewajiban yang segera jatuh tempo. 
Tabel 5

Quick Ratio (CR) PT Japfa Comfeed Indonesia Tbk

\begin{tabular}{|c|c|c|}
\hline Tahun & Quick Ratio & Perkembangan \\
\hline 2014 & $72,72 \%$ & 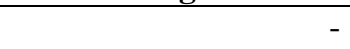 \\
\hline 2015 & $70,04 \%$ & $(3,68 \%)$ \\
\hline 2016 & $107,07 \%$ & $52,86 \%$ \\
\hline 2017 & $100,12 \%$ & $(6,49 \%)$ \\
\hline 2018 & $89,33 \%$ & $(10,77 \%)$ \\
\hline 2019 & $88,88 \%$ & $(0,50 \%)$ \\
\hline Rata-rata Perusahaan & & $88,03 \%$ \\
\hline Standar Industri & & $100 \%$ \\
\hline
\end{tabular}

Sumber : Laporan Keuangan PT Japfa Comfeed Indonesia Tbk (data diolah)

Berdasarkan Tabel 5 pada tahun 2014 rasio cepat perusahaan mendapatkan nilai 72,72\% yang berarti setiap hutang lancar perusahaan sebesar Rp 100,- akan di jamin dengan Rp 72,72,- aset lancar perusahaan setelah dikurangi persediaan. Dari hasil tersebut juga dapat dilihat kondisi rasio lancar tahun 2014 berada dalam kondisi cukup karena nilai rasio cepat masih berada di bawah standar industri.Pada tahun 2015 perusahaan mendapat nilai rasio cepat sebesar 70,04\%, nilai ini mengalami penurunan dari tahun sebelumnya sebesar 3,68\%. Pada tahun 2016 terjadi perkembangan yang cukup besar yakni terjadi peningkatan sebesar 52,86\% menjadi 107,07\%. Hal ini dikarenakan terjadi peningkatan pada aset lancar perusahaan. Pada tahun 2017 nilai rasio cepat perusahaan mengalami penurunan menjadi 100,12\%. Pada tahun 2018 dan 2019 lagi lagi mengalami penurunan pada rasio cepat. Masing-masing mengalami penurunan sebesar 10,77\% dan 0,5\%. Kinerja keuangan PT Japfa Comfeed Indonesia Tbk periode tahun 2014 sampai dengan tahun 2019 memiliki nilai rata-rata perusahaan sebesar 88,03\%, dengan nilai ini perusahaan masuk dalam kategori cukup. Jika bisa di tingkatkan lagi maka mungkin perusahaan akan bisa masuk kategori baik maupun sangat baik.

Debt to total Asset Ratio merupakan rasio yang digunakan untuk mengukur perbandingan antara total hutang dengan total aktiva. Semakin rendah rasio ini menunjukan bahwa semakin baik keaadaan keuangan perusahaan.

Tabel 6

Debt to Total Asset Ratio (DAR) PT Japfa Comfeed Indonesia Tbk

\begin{tabular}{lrr}
\hline Tahun & Debt to Total Asset Ratio & Perkembangan \\
\hline 2014 & $66,37 \%$ & - \\
2015 & $64,39 \%$ & $(2,98 \%)$ \\
2016 & $51,31 \%$ & $4,36 \%$ \\
2017 & $53,55 \%$ & $3,94 \%$ \\
2018 & $55,66 \%$ & $(2,01 \%)$ \\
2019 & $54,54 \%$ & $\mathbf{5 7 , 6 4 \%}$ \\
Rata-rata Perusahaan & & $\mathbf{3 0 \%}$ \\
Standar Industri & & $\mathbf{3 0}$ \\
\hline
\end{tabular}

Sumber : Laporan Keuangan PT Japfa Comfeed Indonesia Tbk (data diolah)

Berdasarkan Tabel 6 dapat dilihat tahun 2014 nilai DAR adalah 66,37\%, yang berarti total aktiva sebesar Rp 100,- dapat menutupi $\mathrm{Rp} 66,37,-$ utang perusahaan. Berdasarkan nilai ini maka dapat dikatakan kondisi perusahaan dinilai kurang baik karena perusahaan dibiayai dengan hutang melebihi rata-rata industri.Pada tahun 2015 nilai DAR perusahaan mengalami penurunan menjadi 64,39\%. Pada tahun 2016 nilai DAR kembali mengalami penurunan yakni sebesar $20,31 \%$ menjadi $51,31 \%$. Hal ini termasuk bagus karena semakin rendah nilai DAR makan semakin baik perusahaan tersebut dalam pembiayaan hutang. Tahun 2017 dan tahun 2018 nilai DAR perusahaan kembali mengalami kenaikan masing-masing sebesar 4,36\% dan 3,94\%. Untuk tahun 2019 nilai DAR perusahaan mengalami penurunan sebesar 2,01\% dari tahun sebelumnya menjadi 54,54\%. Kinerja Keuangan PT Japfa Comfeed Indonesia Tbk periode tahun 2014 sampai dengan 2019 memiliki nilai rata-rata sebesar 57,64\%. Jika di lihat dari standar industri maka perusahaan dapat dikatakan dalam kondisi kurang baik karena nilai tersebut melebihi standar industri. Pada rasio DAR semakin kecil nilai rasio nya akan semakin baik dan sebaliknya jika semakin besak nilai DAR maka perusahaan dikatakan kurang baik. Hal ini dikarenakan perusahaan didanai oleh hutang melebihi batas industri.

Debt to Equity Ratio adalah rasio yang membandingkan utang perusahaan dengan total Ekuitas. Semakin tinggi rasio ini akan menunjukan kinerja yang buruk bagi perusahaan. Maka perusahaan harus berusaha agar DER bernilai rendah atau berada di bawah standar industri yaitu $90 \%$. 
Tabel 7

Debt to Equity Ratio (DER) PT Japfa Comfeed Indonesia Tbk

\begin{tabular}{lrrr}
\hline & Tahun & Debt to Equity Ratio & Perkembangan \\
\hline 2014 & & $197,36 \%$ & - \\
2015 & $180,85 \%$ & $(8,36 \%)$ \\
2016 & $105,38 \%$ & $(41,73 \%)$ \\
2017 & $115,28 \%$ & $9,39 \%$ \\
2018 & $125,53 \%$ & $8,89 \%$ \\
2019 & $119,99 \%$ & $(4,41 \%)$ \\
Rata-rata Perusahaan & & $\mathbf{1 4 0 , 7 3 \%}$ \\
Standar Industri & & & $\mathbf{9 0 \%}$ \\
\hline
\end{tabular}

Sumber : Laporan Keuangan PT Japfa Comfeed Indonesia Tbk (data diolah)

Tabel 7 dapat dilihat tahun 2014 memiliki nilai DER sebesar 197,36\%. Yang berarti ekuitas sebesar Rp 100,dibiayai dengan Rp 197,36,- utang perusahaan. Tahun 2014 memiliki nilai DER terbesar. Nilai standar industri untuk DER adalah sebesar 90\%. Itu artinya, berdasarkan tabel diatas dapat dikatakan kurang baik.Pada tahun 2015 dan 2016 nilai DER perusahaan mengalami penurunan masing-masing sebesar 8,36\% dan 41,73\%. Pada tahun 2017 nilai DER menunjukan nilai sebesar 115,28\%. Pada tahun 2018 nilai DER perusahaan juga kembali mengalami kenaikan sebesar 8,89\% menjadi 125,53\%. Pada tahun 2019 nilai DER mengalami penurunan menjadi 119,99\%. Kinerja Keuangan PT Japfa Comfeed Indonesia Tbk pada periode tahun 2014 sampai dengan 2019 memiliki nilai rata-rata perusahaan untuk DER sebesar 140,73\%. Hal ini dapat dikatakan kurang baik karena nilainya berada di atas standar industri.

Analisis Metode Altman Z-Score

Tabel 8

Debt to Equity Ratio (DER) PT Japfa Comfeed Indonesia Tbk

\begin{tabular}{|c|c|c|c|c|c|c|c|c|}
\hline \multirow{2}{*}{ Tahun } & \multicolumn{5}{|c|}{$\mathrm{Z}=1,2\left(\mathrm{~T}_{1}\right)+1,4\left(\mathrm{~T}_{2}\right)+3,3\left(\mathrm{~T}_{3}\right)+0,6\left(\mathrm{~T}_{4}\right)+0,99\left(\mathrm{~T}_{5}\right)$} & \multirow{2}{*}{ Nilai Z-Score } & \multirow{2}{*}{ Perubahan } & \multirow{2}{*}{ Prediksi } \\
\hline & $\mathrm{T}_{1}$ & $\mathrm{~T}_{2}$ & $\mathrm{~T}_{3}$ & $\mathrm{~T}_{4}$ & $\mathrm{~T}_{5}$ & & & \\
\hline 2014 & 0,241 & 0,153 & 0,034 & 0,968 & 1,555 & 2,74 & - & Grey Area \\
\hline 2015 & 0,248 & 0,163 & 0,041 & 0,611 & 1,458 & 2,47 & $(9,77 \%)$ & Grey Area \\
\hline 2016 & 0,305 & 0,241 & 0,144 & 1,678 & 1,406 & 3,58 & $44,73 \%$ & Sehat \\
\hline 2017 & 0,304 & 0,235 & 0,083 & 1,311 & 1,404 & 3,14 & $(12,10 \%)$ & Sehat \\
\hline 2018 & 0,239 & 0,265 & 0,134 & 1,965 & 1,476 & 3,74 & $19,05 \%$ & Sehat \\
\hline 2019 & 0,205 & 0,289 & 0,102 & 1,310 & 1,459 & 3,22 & $(14,02 \%)$ & Sehat \\
\hline \multicolumn{6}{|c|}{ Rata-rata perusahaan } & 3,15 & & \\
\hline
\end{tabular}

Sumber : Laporan Keuangan PT Japfa Comfeed Indonesia Tbk (data diolah)

Tabel 8 tingkat kebangkrutan PT Japfa Comfeed Indonesia Tbk yang diukur menggunakan metode Altman ZScore pada tahun 2014 adalah 2.74 termasuk kategori "Grey Area atau daerah kelabu". hal ini dikarenakan nilai variabel masih kurang maksimal untuk mencapai tahap kategori "Tidak Bangkrut atau Sehat".Pada tahun 2015 nilai ZScore kembali berada dalam kondisi Grey Area. ini dikarenakan nilai Z-Score tahun 2015 mengalami penurunan sebesar 9,77\% dari tahun sebelumnya menjadi 2.47.Pada tahun 2016 terjadi peningkatan pada nilai Z-Score sebesar 44,73\% menjadi 3,58. Dengan nilai Z-Score tersebut maka perusahaan berada dalam kondisi tidak bangkrut atau sehat. Hal ini karena nilai Z-Score berada di atas 2.99 sehingga dikategorikan tidak bangkrut. Ini di sebabkan karen nilai Laba untuk tahun 2016 terjadi peningkatan dari tahun sebelumnya.Pada tahun 2017 nilai Z-Score adalah 3.14. Walau terjadi penurunan sebesar $12,10 \%$ tetapi nilai Z-Score masih berada dalam kategori tidak bangkrut. Penurunan ini terjadi karena ada nya penurunan pada saldo laba serta harga saham yang juga mengalami penurunan menjadi Rp 1.300.-.Pada tahun 2018 nilai Z-Score adalah 3.74. Nilai ini naik 19,05\% dari tahun sebelumnya. Hal ini disebabkan oleh nilai laba perusahaan mengalami peningkatan serta nilai harga saham ditutup dengan harga Rp 2.150.-. Dengan nilai tersebut maka perusahaan beraada dalam kategori tidak bangkrut.Pada tahun 2019 nilai Z-Score adalah 3,22. Faktor penyebab penurunan nilai Z-Score ini terletak pada variabel $\mathrm{T}_{4}$ yakni nilai pasar ekuitas dimana harga saham kembali merosot ke angka Rp 1.535.-. Meski begitu kodisi perusahaan dinilai dari metode Z-Score masi berada dalam kondisi Tidak Bangkrut.Nilai rata-rata dari Z-Score untuk perusahaan periode 2014 sampai dengan 2019 adalah 3.15. Kenaikan nilai Z-Score pada tahun 2018 ini jika di teliti disebabkan karena nilai dari variabel Market Value of Equity to Book Value of Debt $\left(\mathrm{T}_{4}\right)$ memiliki rasio atau nilai yang paling tinggi yaitu sebesar 1.96 di bandingkan dengan tahun yang lainnya. 


\section{Simpulan}

Penelitian ini bertujuan untuk mengetahui dan menganalisis kinerja keuangan PT Japfa Comfeed Indonesia Tbk periode 2014 sampai dengan 2019 dengan tolok ukur Rasio Keuangan serta prediksi kebangkrutan Metode Altman Z-Score. Berdasarkan hasil penelitian menunjukan bahwa seluruh kinerja keuangan PT Japfa Comfeed Indonesia menunjukan kinerja yang cukupmulai dari tahun 2014 hingga tahun 2019.

\section{Daftar Pustaka}

Betty Koesnina. 2011. Akuntansi SMK/MAK Kelas X. CV Arya Duta. Jakarta.

Erni Agustin. Analisis Rasio Keuangan untuk Menilai Kinerja Keuangan PT Indo Farma Tbk berdasarkan KEP100/MBU/2002. jurnal Ilmu Administrasi Bisnis.

Muharran Haq. 2013. Analisis Rasio Keuangan. Ilmu dan Riset Manajemen.

Munawir S. 2010. Analisis Laporan Keuangan Edisi keempat. Liberty. Yogyakarta.

Supardi. Sri Mastuti. 2003. Validitas Penggunaan Z-Score Altman Untuk Menilai Kebangkrutan Pada Perusahaan Perbankan Go Public di Bursa Efek Jakarta. FE Universitas Teknik Yogyakarta. Yogyakarta. 